\title{
Glutamate receptor-mediated taurine release from the hippocampus during oxidative stress
}

\author{
Brian Tucker $^{1 \dagger}$, James E Olson ${ }^{1,2^{*}+}$ \\ From $17^{\text {th }}$ International Meeting of Taurine \\ Fort Lauderdale, FL, USA. 14-19 December 2009
}

\begin{abstract}
Background: Hippocampal slices swell and release taurine during oxidative stress. The influence of cellular signalling pathways on this process is unclear. Glutamate signalling can facilitate volume regulation in other CNS preparations. Therefore, we hypothesize activation of taurine release by oxidative stress results from tissue swelling and is coupled to activation of glutamate receptors.
\end{abstract}

Methods: Rat hippocampi were incubated at room temperature for $2 \mathrm{hr}$ in artificial cerebrospinal fluid (aCSF) equilibrated with $95 \% \mathrm{O}_{2}$ plus $5 \% \mathrm{CO}_{2}$. For some slices, $1 \mathrm{mM}$ taurine was added to the aCSF to maintain normal tissue taurine content. Slices then were perfused with aCSF at $35^{\circ} \mathrm{C}$ and baseline data recorded before $2 \mathrm{mM} \mathrm{H}_{2} \mathrm{O}_{2}$ was added. For some studies, mannitol or inhibitors of glutamate receptors or the volume-regulated anion channel (VRAC) were added before and during $\mathrm{H}_{2} \mathrm{O}_{2}$ treatment. The intensity of light transmitted through the slice (the intrinsic optical signal, IOS) was determined at 1-min intervals. Samples of perfusate were collected at 2-min intervals and amino acid contents determined by HPLC. Data were analyzed by repeated measures ANOVA and post hoc Dunnett's test with significance indicated for $p<0.05$.

Results: IOS of slices prepared without taurine treatment increased significantly by $3.3 \pm 1.3 \%$ (mean \pm SEM) during oxidative stress. Little taurine was detected in the perfusate of these slices and the rate of taurine efflux did not change during $\mathrm{H}_{2} \mathrm{O}_{2}$ exposure. The $\alpha$-amino-3-hydroxyl-5-methyl-4-isoxazole-propionate antagonist, $25 \mu \mathrm{M} \mathrm{CNQX}$, but not the N-methyl-D-aspartate (NMDA) receptor antagonist, $10 \mu \mathrm{M} \mathrm{MK-801,} \mathrm{inhibited} \mathrm{the} \mathrm{increase} \mathrm{in} \mathrm{IOS} \mathrm{during}$ $\mathrm{H}_{2} \mathrm{O}_{2}$ treatment. Taurine-treated slices exposed to $\mathrm{H}_{2} \mathrm{O}_{2}$ showed no change in IOS; however, taurine efflux increased by $335 \pm 178 \%$. When these slices were perfused with hypertonic aCSF (350 mOsm) or exposed to the VRAC inhibitor, $20 \mu \mathrm{M}$ DCPIB, no increase in the taurine efflux rate was observed during $\mathrm{H}_{2} \mathrm{O}_{2}$ exposure. Taurinetreated slices perfused with $10 \mu \mathrm{M}$ MK-801 during $\mathrm{H}_{2} \mathrm{O}_{2}$ exposure showed a 4.6 $1.9 \%$ increase in IOS but no increase in the taurine efflux rate.

Conclusions: Taurine efflux via VRAC is critical for volume regulation of hippocampal slices exposed to oxidative stress. This increased taurine efflux does not result from direct activation of the taurine release pathway by $\mathrm{H}_{2} \mathrm{O}_{2}$. NMDA receptor activation plays an important role in taurine release during oxidative stress.

\section{Background}

Oxidative stress is observed following brain injury caused by a variety of mechanisms and contributes to secondary brain injury. Brain edema in ischemic and

\footnotetext{
* Correspondence: james.olson@wright.edu

† Contributed equally

'Department of Neuroscience, Cell Biology, and Physiology, Boonshoft

School of Medicine, Wright State University, Dayton, Ohio, USA

Full list of author information is available at the end of the article
}

hemorrhagic stroke is associated with production of reactive oxygen species (ROS) and resultant oxidative stress $[1,2]$. Endogenous and exogenous anti-oxidants reduce edema formation and brain damage following ischemia and reperfusion [1,3-5] and intracerebral hemorrhage $[2,6]$. Reactive oxygen species (ROS) may directly precipitate brain swelling without inducing ischemia or blood-brain barrier injury during intracranial hemorrhage and excitotoxic injury $[7,8]$.

\section{Biomed Central}


In vitro studies have shown oxidative stress can cause brain tissue swelling through activation of glutamate receptors [9]. Because of their direct activation of ion channels and resultant osmotic sequelae, ionotropic glutamate receptors may play a significant role in initiating this brain tissue swelling. Indeed, brain swelling during exposure to $\mathrm{H}_{2} \mathrm{O}_{2}$ is inhibited by ionotropic glutamate receptor antagonists [9]. Brain edema also is modified by metabotropic glutamate receptor activation in certain models of traumatic brain injury and excitotoxicity [10-12]; however, other investigators have seen no effect of the metabotropic group II receptor [12] on injuryinduced brain edema.

In addition to causing brain edema, activation of glutamate receptors may modify the response of CNS cells to swelling through actions on cell volume regulatory mechanisms $[13,14]$. Neurons and glial cells, like many other cell types, facilitate swelling-induced volume regulation by activating volume-regulated anion channels (VRAC) which cause efflux of taurine and other organic osmolytes [15-17]. Thus, glutamatergic signaling during oxidative stress may indirectly lead to brain swelling by modifying this normal cell volume regulation mechanism. This study focuses on ionotropic glutamate signaling during hippocampal oxidative stress. We examine whether this pathway directly induces brain swelling or modifies brain cell volume regulation via the VRAC.

\section{Methods}

All experiments involving animals were approved by the Laboratory Animal Care and Use Committee of Wright State University and conform to the Guide for the Care and Use of Laboratory Animals. Slices of hippocampus were prepared using methods similar to those previously described [18]. Adult Sprague Dawley male rats (275$350 \mathrm{~g}$ ) were anesthetized to apnea with Isoflurane and then perfused over $1 \mathrm{~min}$ via the left cardiac ventricle with $100 \mathrm{ml}$ of ice-cold artificial cerebrospinal fluid (aCSF) consisting of $124 \mathrm{mM} \mathrm{NaCl}, 3.5 \mathrm{mM} \mathrm{KCl}, 2 \mathrm{mM}$ $\mathrm{CaCl}_{2}, 1 \mathrm{mM} \mathrm{MgSO}, 1 \mathrm{mM} \mathrm{NaH} \mathrm{PO}_{4}, 26 \mathrm{mM}$ $\mathrm{NaHCO}_{3}$, and $10 \mathrm{mM}$ glucose. The aCSF osmolality was adjusted to $290 \mathrm{mOsm}$ with additions of small volumes of $3 \mathrm{M} \mathrm{NaCl}$ and was equilibrated with $95 \% \mathrm{O}_{2}$ plus $5 \%$ $\mathrm{CO}_{2}$ prior to use. This perfusion treatment flushed away blood and rapidly chilled the brain tissue. The brain was removed from the head and placed in a slurry of icecold aCSF. After 5-6 min, the hippocampus was dissected from the brain and cut into $400 \mu \mathrm{M}$ slices with a Mcllwain chopper. These slices were incubated for 2-4 $\mathrm{hr}$ in room temperature aCSF that was constantly bubbled with $95 \% \mathrm{O}_{2}$ plus $5 \% \mathrm{CO}_{2}$. Hippocampal slices prepared in this manner lose $70 \%$ to $80 \%$ of endogenous taurine contents [18]. Therefore, for some slices, the
aCSF solutions used during incubation also contained $1 \mathrm{mM}$ taurine to maintain normal taurine contents.

After the room temperature incubation period, slices were transferred to the recording stage of a Haas-type interface chamber and perfused with aCSF equilibrated with $95 \% \mathrm{O}_{2}$ plus $5 \% \mathrm{CO}_{2}$ at $35^{\circ} \mathrm{C}$ under an atmosphere of humidified $95 \% \mathrm{O}_{2}$ plus $5 \% \mathrm{CO}_{2}$. For slices exposed to $1 \mathrm{mM}$ taurine during room temperature incubation, the same taurine concentration was present during the first $30 \mathrm{~min}$ of perfusion on the recording stage. After a total of $90 \mathrm{~min}$ on the recording stage, $2 \mathrm{mM} \mathrm{H}_{2} \mathrm{O}_{2}$ was added to the perfusing aCSF to produce oxidative stress. For slices treated with pharmacological agents, the drugs were added to the aCSF beginning $15 \mathrm{~min}$ prior to the start and then throughout the period of $\mathrm{H}_{2} \mathrm{O}_{2}$ exposure.

The intrinsic optical signal (IOS) was recorded as an indirect measure of changes in tissue volume $[18,19]$. Slices were illuminated with a DC regulated light source while the light transmitted through the slice was recorded with a video camera and captured as uncompressed digital images every $60 \mathrm{sec}$. The average pixel intensity was calculated for identified regions of the stratum radiatum of the CA1 region interest using ImageJ software.

Effluent perfusate from the recording stage was collected continually during the experiments and pooled in $2 \mathrm{~min}$ aliquots. A $1 \mathrm{ml}$ sample was removed from each aliquot, frozen at $-70^{\circ} \mathrm{C}$, lyophilized, and then stored at $-70^{\circ} \mathrm{C}$ for later analysis. The residue was dissolved in 100 $\mu \mathrm{l}$ of distilled water and $65 \mu \mathrm{l}$ was used for HPLC analysis of amino acid concentration following derivatization with o-pthalaldehyde as previously described $[18,20]$.

AMPA ( $\alpha$-amino-3-hydroxyl-5-methyl-4-isoxazole-propionate), CNQX (6-cyano-7-nitroquinoxaline-2,3-dione), and MK-801 ((+)-5-methyl-10,11-dihydro-5H-dibenzo[a,d] cyclohepten-5,10-imine maleate) were obtained from Sigma-Aldrich (St. Louis, Missouri). DCPIB (4-[(2-Butyl6,7-dichloro-2-cyclopentyl-2,3-dihydro-1-ox o-1H-inden5 -yl)oxy]butanoic acid) was purchased from Tocris Biosciences (Ellisville, Missouri). All other chemicals were from Fischer Scientific (Hanover Park, Illinois) and were the highest grade available.

IOS and amino acid contents were analyzed by repeated measures ANOVA followed by post hoc Dunnett's test to compare data obtained during oxidative stress with values measured during the baseline period prior to $\mathrm{H}_{2} \mathrm{O}_{2}$ exposure. Significance was indicated for $\mathrm{p}<0.05$.

\section{Results \\ Taurine is necessary for volume regulation during oxidative stress}

Hippocampal slices prepared with incubation in normal aCSF without added taurine demonstrated a significant increase in IOS during exposure to $\mathrm{H}_{2} \mathrm{O}_{2}$ (Figure 1.A.). 

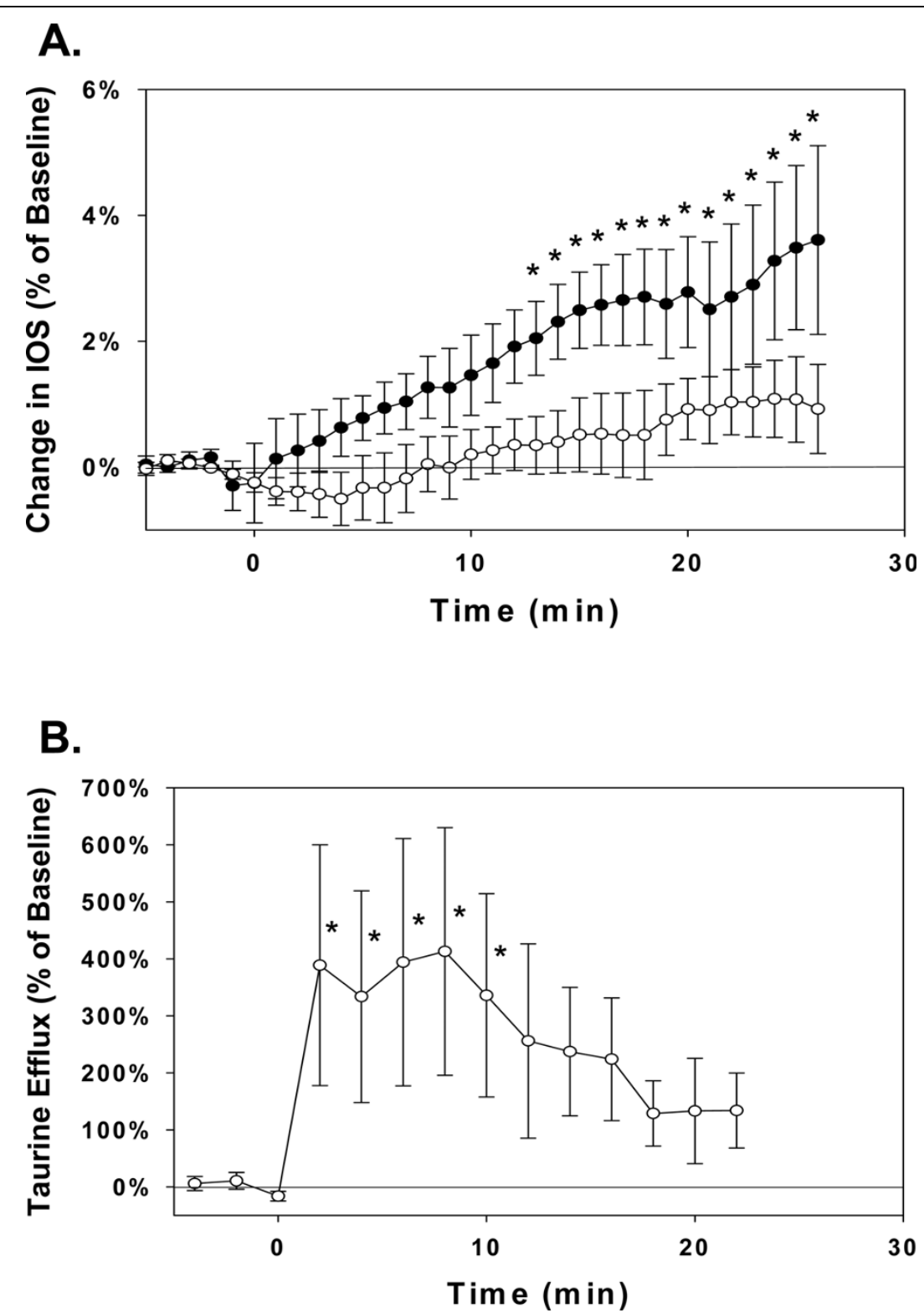

Figure 1 Tissue swelling and taurine efflux from the hippocampus during oxidative stress. Hippocampal slices were perfused with aCSF containing $2 \mathrm{mM} \mathrm{H}_{2} \mathrm{O}_{2}$ from $\mathrm{t}=0$ min to the end of the data sampling period shown. Values are the mean \pm SEM for 3-12 independent measurements. (A) The intrinsic optical signal (IOS) was calculated for areas of the stratum radiatum in the CA1 region of the hippocampus. Slices incubated with normal aCSF during preparation (solid symbols) showed a significant increase in IOS during exposure to $\mathrm{H}_{2} \mathrm{O}_{2}$ while slices incubated with $1 \mathrm{mM}$ taurine (hollow symbols) showed little change in IOS. (B) Taurine concentrations were measured in the effluent of the aCSF that perfused hippocampal slices prepared with $1 \mathrm{mM}$ taurine to maintain normal taurine contents. The taurine concentration in the aCSF perfusate increased significantly at the start of $\mathrm{H}_{2} \mathrm{O}_{2}$ exposure and remained elevated for 10 min. ${ }^{*}$ indicates values which are significantly different from the baseline measurements determined prior to $\mathrm{H}_{2} \mathrm{O}_{2}$ treatment.

Little taurine was measured in the perfusate from these slices and the taurine concentration did not increase during peroxide exposure (data not shown). In contrast, slices incubated with $1 \mathrm{mM}$ taurine showed little swelling throughout the period of oxidative stress while the concentration of taurine in the perfusate increased over 3 -fold during this period (Figure 1.B.).
Taurine efflux occurs via VRAC to control swelling during oxidative stress

We tested whether the increase in taurine release during oxidative stress was due to cell swelling or direct activation of VRAC by $\mathrm{H}_{2} \mathrm{O}_{2}$ [21,22]. For these studies, the osmolality of the aCSF perfusing taurine-treated slices was increased to $350 \mathrm{mOsm}$ with the addition of 
mannitol for 15 min prior to adding $2 \mathrm{mM} \mathrm{H}_{2} \mathrm{O}_{2}$ to the perfusate. Mannitol treatment markedly and rapidly decreased the IOS by $17.0 \pm 2.2 \%$ within $10 \mathrm{~min}$ (mean \pm SEM). No increase in taurine efflux was observed in these slices during the subsequent exposure to oxidative stress.

In the presence of the VRAC inhibitor, $20 \mu \mathrm{M}$ DCPIB [23], slices incubated with taurine and then perfused with normal aCSF (290 mOsm) demonstrated an increase in IOS but no increase in taurine efflux during exposure to $2 \mathrm{mM} \mathrm{H}_{2} \mathrm{O}_{2}$ (Table 1).

\section{Glutamate signalling is coupled to volume regulation during oxidative stress}

To examine the role of glutamate signalling for oxidative stress-induced swelling and volume regulation, hippocampal slices were exposed to an inhibitor of either Nmethyl-D-aspartate (NMDA) receptors $(10 \mu \mathrm{M}$ MK-801) or AMPA receptors $(25 \mu \mathrm{M}$ CNQX). In slices without taurine treatment, no change in IOS was observed when $2 \mathrm{mM} \mathrm{H}_{2} \mathrm{O}_{2}$ was added to the perfusate in the presence of CNQX. This suggests AMPA receptors contribute to the mechanisms of swelling induced by oxidative stress. In contrast, in the presence of MK- 801 , the mean \pm SEM IOS increased by $1.8 \pm 0.2 \%$ during 25 min of peroxide exposure; a value that is similar to that observed in the absence of drug (Figure 1). However, when taurine-treated slices were exposed to $\mathrm{H}_{2} \mathrm{O}_{2}$ in the presence of MK801 , a significant increase in IOS was seen, and the rate of taurine efflux was not altered (Table 1).

\section{Discussion}

The results of these experiments illuminate several mechanisms for swelling and volume regulation of the hippocampus exposed to oxidative stress. First, the data demonstrate the importance of intracellular taurine for volume regulation in this condition. We previously demonstrated that hippocampal slices lose the majority of their taurine content during preparation and incubation unless exogenous taurine is added to the incubation solutions [18]. Our previous data also demonstrated that a normal tissue taurine content was critical for volume regulation of the hippocampus swollen by exposure to hypoosmotic conditions. The present results reveal a similar requirement of normal taurine content for volume regulation during exposure to oxidative stress in isoosmotic conditions. Furthermore, inhibition of oxidative stress-induced taurine efflux by the VRAC antagonist, DCPIB, and the tissue swelling which results in the presence of this drug, indicates that taurine efflux is necessary for the volume regulatory response. Others have demonstrated the release of amino acids through VRAC channels during exposure to hypoosmotic conditions and oxidative stress [24-26]. We characterized VRAC in rat astrocytes and neurons in primary culture during exposure to hypoosmotic conditions $[16,27]$ and showed that taurine efflux via VRAC is necessary for hypoosmotic volume regulation in the hippocampus [18]. Inhibition of oxidative stress-induced taurine efflux by pre-treatment with hyperosmolar aCSF demonstrates that $\mathrm{H}_{2} \mathrm{O}_{2}$ is not acting directly on VRAC to induce taurine efflux as has been observed in cell culture preparations $[21,28]$.

Our data also suggest that the AMPA subtype of ionotropic glutamate receptors contributes to hippocampal swelling induced by oxidative stress while NMDA receptors have little effect. Previous reports have shown that swelling of hippocampal slices exposed to $\mathrm{H}_{2} \mathrm{O}_{2}$ for 1-3 hours can be blocked using a cocktail of glutamate receptor inhibitors; however, individual contributions of NMDA and AMPA receptors for the swelling response were not elucidated [29]. We did not examine the effects of metabotropic glutamate receptors in the brain tissue swelling response. Potentially, activation of group I or group II receptors may indirectly exacerbate or reduce swelling, respectively, by modifying endogenous glutamate release and resulting stimulation of ionotropic receptors $[10,11,30]$.

Finally, our results demonstrate that glutamate signaling via NMDA receptors plays an important role in volume regulation of the hippocampus during oxidative stress. Since oxidative stress-induced swelling itself is blocked by CNQX, we could not determine whether AMPA receptors also may be involved in the volume regulatory response. We and others have described several signaling pathways involved in cell volume

Table 1 Drug effects on tissue swelling and taurine efflux from the hippocampus during oxidative stress

\begin{tabular}{ccc}
\hline Drug Treatment & $\begin{array}{c}\mathbf{H}_{\mathbf{2}} \mathbf{O}_{\mathbf{2}} \text {-induced Change in IOS } \\
\text { (Percent of Baseline) }\end{array}$ & $\begin{array}{c}\mathbf{H}_{\mathbf{2}} \mathbf{O}_{\mathbf{2}} \text {-induced Change in Taurine Efflux Rate } \\
\text { (Percent of Baseline) }\end{array}$ \\
\hline None & $0.7 \pm 0.6 \%$ & $335 \pm 178 \% *$ \\
$20 \mu$ M DCPIB & $3.2 \pm 1.0 \% *$ & $-11 \pm 29 \%$ \\
$10 \mu$ M MK-801 & $4.6 \pm 1.9 \% *$ & $-55 \pm 13 \%$ \\
\hline
\end{tabular}

All experiments were performed using hippocampal slices prepared with $1 \mathrm{mM}$ taurine to maintain normal taurine contents. Changes in the intrinsic optical signal (IOS) measured in the stratum radiatum of the $\mathrm{CA} 1$ region and the taurine efflux rate were determined after 25 min and 8 min of $\mathrm{H}_{2} \mathrm{O}_{2}$ exposure, respectively. These represent time points which resulted in peak responses observed in control slices with no drug treatment as shown in Figure 1 . Values are the mean \pm SEM for 3-5 independent measurements. * Indicates values which are significantly different from baseline measurements determined prior to $\mathrm{H}_{2} \mathrm{O}_{2}$ treatment. 
regulation and associated amino acid efflux from brain cells. These include the calcium/calmodulin pathway [24,31,32], nucleotide receptors [16,26], arachidonate metabolism [22,33] and glutamate receptor activation $[13,14]$. The relationships between these pathways as well as the interactions between glia and neurons which facilitate brain volume regulation have not yet been fully described. Greater understanding of these mechanisms will lead to improved treatments for brain edema and will reduce the degree of permanent brain damage in patients who suffer brain injury.

\section{Conclusions}

1. Release of taurine from intracellular stores is critical for isoosmotic volume regulation of the hippocampus exposed to oxidative stress.

2. Taurine is lost from hippocampal cells during oxidative stress via the volume activated anion channel (VRAC).

3. AMPA receptors, but not NMDA receptors are coupled to hippocampal swelling during oxidative stress.

4. Volume regulation of the hippocampus is regulated, in part, by glutamate signaling via NMDA receptors.

\section{List of abbreviations}

aCSF, artificial cerebrospinal fluid; AMPA, $\alpha$-amino-3-hydroxyl-5-methyl-4isoxazole-propionate; CNQX, 6-cyano-7-nitroquinoxaline-2,3-dione; DCPIB, 4[(2-Butyl-6,7-dichloro-2-cyclopentyl-2,3-dihydro-1-ox o-1H-inden-5-yl)oxy] butanoic acid; IOS, intrinsic optical signal; MK-801, (+)-5-methyl-10,11dihydro-5H-dibenzo[a,d]cyclohepten-5,10-imine maleate; NMDA, N-methyl-Daspartate; ROS, reactive oxygen species; VRAC, volume-regulated anion channel.

\section{Acknowledgements}

The authors thank James Leasure for assistance provided during preparation of the hippocampal slices and HPLC analysis of taurine contents.

This article has been published as part as part of Journal of Biomedical Science Volume 17 Supplement 1, 2010: Proceedings of the 17th International Meeting of Taurine. The full contents of the supplement are available online at http://www.jbiomedsci.com/supplements/17/S1.

\section{Author details}

${ }^{1}$ Department of Neuroscience, Cell Biology, and Physiology, Boonshoft School of Medicine, Wright State University, Dayton, Ohio, USA. ${ }^{2}$ Department of Emergency Medicine, Boonshoft School of Medicine, Wright State University, Dayton, Ohio, USA.

\section{Authors' contributions}

Both authors contributed to the conception of the study and its design. BT carried out the majority of the experimental studies and the analytical and statistical analyses. JO drafted the manuscript, but both authors contributed to its completion. Both authors read and approved the final manuscript.

\section{Competing interests}

Neither of the authors has competing interests regarding this manuscript.

Published: 24 August 2010

\section{References}

1. Deng XL, Qian ZY, Liu NF, Ma XY, Wang HF, Hou ZJ: Antagonistic effect of 3,6-dimethamidodibenzopyriodonium gluconate on lipid peroxidation in cerebral cortical neuronal cultures and rat brains during focal cerebral ischemia reperfusion. 2000, 21:460-462.
2. Wagner KR, Hua Y, de Courten-Myers GM, Broderick JP, Nishimura RN, LU SY, Dwyer BE: Tin-mesoporphyrin, a potent heme oxygenase inhibitor, for treatment of intracerebral hemorrhage: in vivo and in vitro studies. Cell Mol Biol 2000, 46(3):597-608.

3. Daneyemez M, Kurt E, Cosar A, Yuce E, Ide T: Methylprednisolone and vitamin $E$ therapy in perinatal hypoxic-ischemic brain damage in rats. Neuroscience 1999, 92:693-697.

4. Cuzzocrea S, Costantino G, Gitto E, Mazzon E, Fulia F, Serraino I, Cordaro S, Barberi I, De Sarro A, Caputi AP: Protective effects of melatonin in ischemic brain injury. J Pineal Res 2000, 29:217-227.

5. Kim SO, Cho IS, Gu HK, Lee DH, Lim H, Yoo SE: KR-31378 protects neurons from ischemia-reperfusion brain injury by attenuating lipid peroxidation and glutathione loss. Eur J Pharmacol 2004, 487:81-91.

6. Nakamura T, Keep RF, Hua Y, Schallert T, Hoff JT, Xi G: Deferoxamineinduced attenuation of brain edema and neurological deficits in a rat model of intracerebral hemorrhage. J Neurosurg 2004, 100(4):672-678.

7. Wu J, Hua $Y$, Keep RF, Schallert T, Hoff JT, Xi G: Oxidative brain injury from extravasated erythrocytes after intracerebral hemorrhage. Brain Res 2002, 953(1-2):45-52.

8. Marini $H$, Altavilla D, Bellomo M, Adamo EB, Marini R, Laureanti $F$, Bonaccorso MC, Seminara P, Passaniti M, Minutoli $L$, et al: Modulation of IL1 beta gene expression by lipid peroxidation inhibition after kainic acidinduced rat brain injury. Exp Neurol 2004, 188:178-186.

9. Avshalumov MV, Rice ME: NMDA receptor activation mediates hydrogen peroxide-induced pathophysiology in rat hippocampal slices. $J$ Neurophysiol 2002, 87:2896-2903.

10. Fei Z, Zhang X, Bai HM, Jiang XF, Wang XL: Metabotropic glutamate receptor antagonists and agonists: potential neuroprotectors in diffuse brain injury. J Clin Neurosci 2006, 13:1023-1027.

11. Colwell CS, Levine MS: Metabotropic glutamate receptor modulation of excitotoxicity in the neostriatum: role of calcium channels. Brain Res 1999, 833:234-241.

12. Stover JF, Sakowitz OW, Beyer TF, Dohse NK, Kroppenstedt SN, Thomale UW, Schaser KD, Unterberg AW: Effects of LY379268, a selective group II metabotropic glutamate receptor agonist on EEG activity, cortical perfusion, tissue damage, and cortical glutamate, glucose, and lactate levels in brain-injured rats. J Neurotrauma 2003, 20:315-326.

13. Wurm A, Pannicke T, Wiedemann P, Reichenbach A, Bringmann A: Glial cell-derived glutamate mediates autocrine cell volume regulation in the retina: activation by VEGF. J Neurochem 2008, 104(2):386-399.

14. Garcia Dopico J, Perdomo Diaz J, Alonso TJ, Gonzalez Hernandez T, Castro Fuentes R, Rodriguez Diaz M: Extracellular taurine in the substantia nigra: taurine-glutamate interaction. J Neurosci Res 2004, 76:528-538.

15. Kimelberg HK: Increased release of excitatory amino acids by the actions of ATP and peroxynitrite on volume-regulated anion channels (VRACs) in astrocytes. Neurochem Int 2004, 45:511-519.

16. Li G, Olson JE: Purinergic activation of anion conductance and osmolyte efflux in cultured rat hippocampal neurons. Am J Physiol Cell Physiol 2008, 295:C1550-C1560.

17. Olson JE, Li GZ: Increased potassium, chloride, and taurine conductances in astrocytes during hypoosmotic swelling. Glia 1997, 20:254-261.

18. Kreisman NR, Olson JE: Taurine enhances volume regulation in hippocampal slices swollen osmotically. Neuroscience 2003, 120(3):635-642.

19. Andrew RD, MacVicar BA: Imaging cell volume changes and neuronal excitation in the hippocampal slice. Neuroscience 1994, 62:371-383.

20. Olson JE: Osmolyte contents of cultured astrocytes grown in hypoosmotic medium. Biochem Biophys Acta 1999, 1453:175-179.

21. Varela D, Simon F, Riveros A, Jorgensen F, Stutzin A: NAD(P)H oxidasederived $\mathrm{H}(2) \mathrm{O}(2)$ signals chloride channel activation in cell volume regulation and cell proliferation. J Biol Chem 2004, 279:13301-13304.

22. Lambert $\mathrm{IH}$ : Reactive oxygen species regulate swelling-induced taurine efflux in NIH3T3 mouse fibroblasts. J Membr Biol 2003, 192:19-32.

23. Abdullaev IF, Rudkouskaya A, Schools GP, Kimelberg HK, Mongin AA: Pharmacological comparison of swelling-activated excitatory amino acid release and $\mathrm{Cl}$ - currents in cultured rat astrocytes. J Physiol 2006, 572:677-689.

24. Haskew-Layton RE, Mongin AA, Kimelberg HK: Hydrogen peroxide potentiates volume-sensitive excitatory amino acid release via a mechanism involving $\mathrm{Ca} 2+/$ calmodulin-dependent protein kinase II. $J$ Biol Chem 2005, 280:3548-3554 
25. Haskew-Layton RE, Rudkouskaya A, Jin Y, Feustel PJ, Kimelberg HK, Mongin AA: Two distinct modes of hypoosmotic medium-induced release of excitatory amino acids and taurine in the rat brain in vivo. PLoS One 2008, 3:e3543.

26. Mongin AA, Kimelberg HK: ATP regulates anion channel-mediated organic osmolyte release from cultured rat astrocytes via multiple $\mathrm{Ca} 2$ +-sensitive mechanisms. Am J Physiol Cell Physiol 2005, 288:C204-C213.

27. Li G, Olson JE: Cell volume modifies an ATP-sensitive anion conductance in cultured hippocampal astrocytes. Adv Exp Biol Med 2004, 559:405-406.

28. Harrigan TJ, Abdullaev IF, Jourd'heuil D, Mongin AA: Activation of microglia with zymosan promotes excitatory amino acid release via volume-regulated anion channels: the role of NADPH oxidases. J Neurochem 2008, 106:2449-2462.

29. Brahma B, Forman RE, Stewart EE, Nicholson C, Rice ME: Ascorbate inhibits edema in brain slices. J Neurochem 2000, 74:1263-1270.

30. Yuan F, Wang T, Luo L, Sun Y, Zhang L, Qu B: Development of cytotoxic cerebral edema in rats following intracaudatum injection of $\mathrm{AACPD}$, an agonist of metabotropic glutamate receptors. Chin Med J (Engl) 2000, 113:728-732.

31. Li G, Liu Y, Olson JE: Calcium/calmodulin-modulated chloride and taurine conductances in cultured rat astrocytes. Brain Res 2002, 925:1-8.

32. Olson JE, Li GZ, Wang L, Lu L: Volume-regulated anion conductance in cultured rat cerebral astrocytes requires calmodulin activity. Glia 2004, 46:391-401.

33. Strange K, Morrison R, Shrode L, Putnam R: Mechanism and regulation of swelling-activated inositol efflux in brain glial cells. Am J Physiol 1993, 265:C244-C256.

doi:10.1186/1423-0127-17-S1-S10

Cite this article as: Tucker and Olson: Glutamate receptor-mediated

taurine release from the hippocampus during oxidative stress. Journal of Biomedical Science 2010 17(Suppl 1):S10.

\section{Submit your next manuscript to BioMed Central and take full advantage of:}

- Convenient online submission

- Thorough peer review

- No space constraints or color figure charges

- Immediate publication on acceptance

- Inclusion in PubMed, CAS, Scopus and Google Scholar

- Research which is freely available for redistribution

Submit your manuscript at www.biomedcentral.com/submit 